\title{
Розділ 2
}

\section{ТЕОРІЯ ТА ПРАКТИКА НАВЧАННЯ I ВИХОВАННЯ} CHAPTER 2

\section{THEORY AND PRACTICE OF EDUCATION}

\author{
УДК 378.01
}

DOI: 10.31376/2410-0897-2019-2-40-79-90

\section{НАВЧАЛЬНО-МЕТОДИЧНИЙ СУПРОВІД ФОРМУВАННЯ ЕКОНОМІЧНОЇ КОМПЕТЕНТНОСТІ МАЙБУТНІХ УЧИТЕЛІВ ТЕХНОЛОГІЙ}

\author{
Курок Віра Панасівна \\ доктор педагогічних наук, професор, завідувач кафедри технологічної і професійної освіти \\ Глухівський національний педагогічний університет імені Олександра Довженка \\ e-mail: virakurok@,gmail.com \\ ORCID ID: 0000-0003-1474-3879

\section{Кондратенко Тетяна Володимирівна} \\ кандидат педагогічних наук \\ Глухівський національний педагогічний університет імені Олександра Довженка \\ e-mail: tetainakondratenko@gmail.com \\ ORCID ID: 0000-0002-8177-8433
}

\begin{abstract}
Визначено сутність навчально-методичного супроводу формування економічної компетентності майбутніх учителів технологій як комплекс навчально-методичної документації та засобів навчання, спрямованих на реалізацію педагогічних умов й ефективне функиіонування розробленої моделі. Окреслено напрями формування економічної компетентності здобувачів освіти в прочесі фахової підготовки. Схарактеризовано окремі форми і методи формування означеної якості майбутніх фахівиів з урахуванням педагогічних умов та шляхів їх ефективної реалізачії.
\end{abstract}

Ключові слова: майбутні вчителі технологій; економічна компетентність; педагогічна умова; навчально-методичний супровід.

Постановка проблеми. Для забезпечення фахової підготовки конкурентоспроможного педагога в умовах сьогодення заклад вищої педагогічної освіти має розробити та впровадити особистісно орієнтовану іiі модель. Міжпредметні зв'язки освітньої галузі «Технології» та економічних навчальних предметів у освітньому процесі закладів загальної середньої освіти зумовили актуалізацію проблеми формування економічної компетентності майбутніх учителів технологій. За цих обставин логічним $є$ питання щодо створення навчально-методичного супроводу означеного процесу.

Аналіз останніх досліджень і публікацій. Питання навчально-методичного супроводу та його впровадження в освітній процес закладу вищої педагогічної освіти вивчалося О. Ковтун, М. Прохоровим, О. Філатовою та іншими науковцями.

За тлумаченням В. Бусела, «супровід - те, що супроводить яку-небудь дію, явище» [1, с. 1415].

Водночас О. Філатова і М. Прохорова трактують «методичний супровід освітнього процесу» як «систему нормативної та навчально-методичної документації, засобів навчання $\mathrm{i}$ контролю, необхідних для проектування та реалізації компетентністної моделі фахівця» [6].

О. Ковтун розуміє навчально-методичний супровід освітнього процесу «як комплекс заходів, визначених на основі досягнень науки, практики і спрямованих на розроблення науково обгрунтованих нормативно-методичних, навчально-програмних, навчальнометодичних документів, інформаційних матеріалів, засобів навчання» [2, с. 54]. Його основними компонентами дослідниця вважає навчальну документацію та засоби навчання, «які є носіями змісту навчання й методами його фіксації» [2, с. 55]. 
Таким чином, навчально-методичний супровід формування економічної компетентності майбутніх учителів технологій у процесі фахової підготовки $є$ комплексом навчальнометодичної документації та засобів навчання, спрямованих на реалізацію педагогічних умов й ефективне функціонування розробленої моделі.

3 огляду на це метою публікації $є$ обгрунтування навчально-методичного супроводу для формування економічної компетентності майбутніх фахівців у процесі фахової підготовки.

Виклад основного матеріалу. У процесі проведеного дослідження виявлено та теоретично обгрунтовано педагогічні умови формування економічної компетентності майбутніх учителів технологій: знань;

1) формування позитивної мотивації в майбутніх фахівців до засвоєння економічних

2) удосконалення змісту економічної підготовки майбутніх учителів технологій у закладах вищої педагогічної освіти;

3) застосування інформаційно-комунікаційних технологій в освітньому процесі з метою формування економічної компетентності майбутніх учителів технологій;

4) запровадження завдань економічного змісту на технологічну і педагогічну практики.

Формування позитивної мотивації у майбутніх фахівців до засвоєння економічних знань - утілення однієї з педагогічних умов - здійснювалося наскрізно через усі складники моделі шляхом формування в майбутніх учителів технологій мотиваційного компонента економічної компетентності: сформованість у студентів потреби у засвоєнні економічної інформації, ціннісного ставлення до економічних знань, наявність вольових якостей особистості (наполегливість в оволодінні економічними знаннями, активність i цілеспрямованість майбутніх учителів технологій на досягнення результатів у економічній підготовці).

У теоретичній частині експериментального дослідження була акцентована увага майбутніх учителів технологій на спільності змістових ліній понять «освіта», «праця» та «економіка», адже фундаментальною є діяльність людини як продуктивної сили, спрямованої на задоволення власних потреб, реалізацію особистісного інтелектуального та творчого потенціалу. В освітньому процесі нами була розкрита сутність понять «компетентність», «економічна компетентність», «економічна компетентність майбутнього учителя технологій». Історично їх зміст поступово розвивався та поглиблювався, суспільством усвідомлювалося їх значення, набуваючи актуальності в умовах сьогодення, що і має стати невід'ємним складником професійної компетентності майбутніх учителів технологій.

Розкриваючи навчальний матеріал 3 тем та питань економічних навчальних дисциплін, викладачі активізовували роботу студентів, залучаючи їх до обговорення проблем, обміну думками, що сприяло кращому засвоєнню навчального матеріалу та розумінню ними ролі економічних знань, їх значення у формуванні компетентного вчителя технологій.

Для підвищення мотивації здобувачів освіти до набуття економічних знань переважна більшість завдань була виконана індивідуально, мала диференційований характер. Заохочувалася науково-пошукова робота студентів, що було враховано під час оцінювання знань. Під час викладання навчального матеріалу економічного змісту особливу увагу майбутніх учителів технологій звертали на зв'язок з обраною професією, що підвищувало пізнавальну мотивацію.

Пізнавальна активність студентів зростала під час вирішення навчальних ситуацій, коли вони брали безпосередню участь в освітньому процесі закладу загальної середньої освіти: проведенні уроків трудового навчання та технологій із застосуванням міжпредметних зв'язків 3 економікою, навчального предмета «Економіка» 3 використанням інформаційнокомунікаційних технологій та інтерактивних освітніх технологій. Завершувалася така робота обговореннями $з$ викладачем, дискусіями, висловлюванням власних думок, обміном думками між одногрупниками, самоаналізом власних пізнавальних та практичних дій.

В освітньому процесі застосовувалися нетрадиційні форми лекцій. Зокрема, з теми «Економічна освіта у формуванні економічних знань особистості» була проведена проблемна 
лекція. До активної діяльності майбутні фахівці були залучені у процесі пошуку відповідей на питання: становлення економічної освіти в системі загальної середньої освіти в Україні; методика та засоби навчання економічних предметів, економічне виховання в системі загальної середньої освіти. Після постановки проблеми викладач демонстрував свої напрацювання та міркування 3 теми, застосовуючи порівняльний аналіз, студенти висловлювали власні думки, гіпотези, обговорюючи їх між собою та з викладачем. За цих умов було досягнуто логіки побудови проблемної лекції - навчальне пізнання стало науковим опрацюванням теми.

Проблемний виклад навчального матеріалу спрямовує до вмотивованого пошуку, вивчення, систематизації та узагальнення здобутих економічних знань, усвідомлення їх практичного застосування, подальшої рефлексії. Проблемне навчання забезпечує якість сприйняття економічної інформації, формує активність пізнавальної діяльності студентів, їх самостійність, усвідомлення власної потреби у здобутті економічних знань, умінь, навичок.

Зацікавленість студентів економічною інформацією, що є установкою на оволодіння економічними дисциплінами та формування у них пізнавальних мотивів, в експериментальній роботі підвищувалася через суб'єкт-суб'єктні відносини між викладачем і студентом в освітньому процесі, зокрема під час проходження технологічної і педагогічної практик; проведення зустрічей із досвідченими фахівцями в галузі економіки; застосування міждисциплінарних зв'язків та зв'язку із життям; використання інноваційних методів викладання; проведення міні-тренінгу «Вміння, які визначають успішність економічної діяльності», що стимулював вироблення власного ставлення до професійної діяльності та був спрямований на оволодіння власними ефективними прийомами пізнавальної діяльності.

Відповідно до педагогічної умови посилилася спільна діяльність викладача та студента в освітньому процесі. Викладач стає тьютором та консультантом, студент займає активну й творчу позицію, посилюється мотивація до економічних знань, з'являється вміння виявляти та аналізувати проблему, знаходити шляхи іï вирішення, економічно обгрунтовувати та ухвалювати власне рішення, формується економічне мислення майбутнього вчителя технологій.

Важливою педагогічною умовою формування економічної компетентності в процесі фахової підготовки є вдосконалення змісту економічної підготовки майбутніх учителів технологій у закладах вищої педагогічної освіти. Практичне значення такого вдосконалення грунтується на поступовому накопиченні в студентів економічних знань, практичних навичок та вмінь, поетапному формуванні в них економічної компетентності.

Економіка є об’єктивною й однією 3 найважливіших галузей життєдіяльності суспільства та середовищем життя людини. Економічна теорія є суспільною теоретичною наукою, що вивчає систему знань про відносини між людьми в процесі їхнього господарського життя. Відповіді на ключові економічні питання суспільства на історичних етапах його розвитку містить навчальна дисципліна «Основи економічної теорії», унесена закладами вищої педагогічної освіти до навчальних планів підготовки бакалаврів.

Потенційні можливості щодо формування економічної компетентності майбутніх учителів технологій мають навчальні дисципліни «Історія та основи техніки і технологій», «Обробка конструкційних матеріалів».

У межах навчальної дисципліни «Історія та основи техніки і технологій» запропоновані до вивчення питання, що поглиблюють знання майбутніх учителів технологій, пов'язані 3 вимогами до якості процесу виробництва та готової продукції, організації іiі забезпечення, із залученням навчального матеріалу тем «Основні технологічні процеси на виробництві», «Оцінка та вибір технологічних рішень на підприємстві».

Для посилення економічної складової фахової підготовки майбутніх учителів технологій $з$ навчальної дисципліни «Обробка конструкційних матеріалів» тема «Обробка металів осьовим різальним інструментом» доповнена питанням «Вплив вибору та зносу інструменту на собівартість виготовлення деталей», тема «Обробка металів на металорізальних верстатах» розширена питанням «Втрати металу в процесі обробки металів 
різанням. Припуски на обробку заготовок. Вартість деталі, обробленої різанням», до теми «Різальні інструменти для деревообробних верстатів» додане для вивчення студентами питання «Вплив вибору та зносу різця на собівартість виробу 3 деревини», зміст теми «Обробка деревини на деревообробних верстатах» поглиблений питанням «Продуктивність $\mathrm{i}$ точність обробки деревини різанням».

Навчальна дисципліна економічного спрямування «Економіка i організація виробництва» збагачена навчальним матеріалом, що має прикладний характер та спрямований на поглиблення економічних знань студентів, усвідомлення майбутніми бакалаврами їх значення в ухваленні економічно обгрунтованих рішень. Охарактеризуємо змістове наповнення кожного з цих питань.

Так, тема «Витрати виробництва, собівартість та рентабельність продукції» доповнена питанням «Ціноутворення», від розуміння економічного механізму якого залежить фінансовий результат діяльності підприємства. Оновлений навчальний матеріал ураховує вивчення студентами поняття «ціна» як економічної категорії, iї функцій та класифікації, ціноутворення та диференціації цін, формування ціни підприємствами.

Розширення теми «Значення технічної та технологічної підготовки виробництва, іiі завдання» питанням «Організація переходу на випуск нових видів продукції» актуалізується в умовах ринкової економіки, грунтується на маркетингових дослідженнях ринку збуту готової продукції та розкриває особливості технологічної й організаційної підготовки виробництва, організації переходу до випуску нових видів продукції.

Ефективність капіталовкладень та інвестицій у темі «Виробничі інвестиції підприємства» врахована за допомогою введення питання «Ефективність інженерних та господарських рішень (методика розрахунку сукупного ефекту від створення нової продукції)», що розкриває: сутнісні характеристики інженерного та господарського рішень, ефективність як результат їх упровадження та діяльності підприємства в цілому, господарське рішення як раціональний вибір, сутнісний зміст привабливості інвестицій, визначення строку їх окупності.

У дослідженні запропоновано збагачення змісту програмового матеріалу підготовки майбутніх бакалаврів уведенням змістового модуля «Методика навчання економіки» до програми навчальної дисципліни «Методика навчання технологій» циклу професійної та практичної підготовки. Предметом вивчення змістового модуля є дидактичні особливості застосування методів, технологій і форм навчання учнів закладів загальної середньої освіти навчального предмета «Економіка».

Метою змістового модуля «Методика навчання економіки» є забезпечення практичної й методичної готовності студентів до організації і проведення урочної та позаурочної навчальновиховної роботи з навчального предмета «Економіка».

У результаті засвоєння змістового модуля майбутні вчителі технологій повинні знати: структуру, зміст навчальних програм предмета «Економіка»; його методичне забезпечення; характер і зміст роботи вчителя щодо організації, планування і матеріального забезпечення навчання учнів у закладах загальної середньої освіти.

Майбутні вчителі технологій у результаті опанування навчальної дисципліни повинні вміти: готуватися до теоретичних і практичних занять, правильно будувати й проводити ці заняття; складати потрібну для занять навчально-методичну документацію; правильно організовувати освітню діяльність учнів; застосовувати міжпредметні зв'язки; правильно здійснювати зв'язок теоретичних занять 3 практичними роботами учнів, а всієї економічної підготовки - з основами наук; поєднувати навчання, виховання і розвиток учнів у процесі урочної й позаурочної роботи з економічного навчання.

Основними формами підготовки майбутніх бакалаврів визначені лекції, практичні заняття, самостійна та індивідуальна робота.

Під час викладання змістового модуля «Методика навчання економіки» посилена спільна діяльність викладача та студента шляхом упровадження таких організаційних форм занять: нетрадиційні лекції (лекція-зворотний зв'язок, лекція-дискусія, лекція-консультація, 
лекція-аналіз, лекція проблемна), семінарські заняття (конференція, колоквіум, бесіда), практичні роботи (рольова гра шляхом моделювання ситуації з використанням інтерактивної методики »5 3 25» (практична робота 3 теми «Обрання та застосування методів організації навчання учнів 3 економіки. Методи навчання економічних предметів учнів у закладах загальної середньої освіти»), метод «Мозаїка» (практична робота за темою «Економічне виховання учнів в процесі трудового навчання та виховання»)), тестові завдання, самостійна та індивідуальна робота студентів (виконання творчої наукової роботи за індивідуальним завданням, підготовка та виступ 3 рефератом на одну із запропонованих тем, написання курсової роботи).

Завданням практичної роботи студентів, тотожним очікуваному результату навчальнопізнавальної діяльності учнів, є прогнозування якості виготовлення, вартості та сфери застосування виробу [5].

У процесі викладання навчального змістового модуля «Методика навчання економіки» доцільно застосувати такі методи:

- проблемний: реалізується через виконання студентами індивідуальних науководослідних завдань, що відбувається у формі написання рефератів, тез доповідей, наукових публікацій, підготовки та захисту власних економічних обгрунтувань, висновків, досліджень. Результати науково-дослідної роботи реалізуються на конкурсах наукових робіт студентів, олімпіадах, конференціях та семінарах, засіданнях круглих столів;

- дискусія: сприяє розвитку економічного мислення майбутніх учителів технологій, налагоджує комунікативний зв'язок «викладач - студент», забезпечує поглиблення знань студентів, набуття вмінь аргументовано доводити власну думку, формує професійну етику; вчить студентів логічно викладати свої думки та обгрунтовувати їх істинність;

- ділова гра: наближає навчальний процес до реальних умов шляхом імітування майбутніми вчителями технологій освітнього процесу на заняттях за попередньо розробленим сценарієм, зокрема проведення уроків у закладі загальної середньої освіти;

- круглий стіл: забезпечує ефективність засвоєння знань студентами, наприклад, у ході проведення міждисциплінарних занять 3 опертям на міждисциплінарні зв'язки навчальних предметів освітньої галузі «Технології» та економіки за участі досвідчених викладачів та вчителів, професіоналів та фахівців галузей економіки;

- проектів: передбачає застосування майбутніми вчителями технологій інтегрованих знань у розв'язанні проблеми з проведенням науково-дослідної роботи, що будується на засадах їхньої співтворчості з викладачами. Цей метод дає змогу організувати самостійну роботу студентів, що має пізнавальний характер та формує в них професійну самостійність;

- моделювання: дозволяє майбутнім учителям технологій обговорювати проблеми, пов'язані з їхньою майбутньою педагогічною діяльністю; інтегрує отримані економічні знання, уміння та навички в цілісну систему; розвиває особисті та професійні якості; формує професійні вміння, здатність самостійно ухвалювати рішення в практичних ситуаціях;

- інтерактивні: забезпечують взаємодію «викладач-студент», під час якої викладач $\epsilon$ організатором (тьютором). Засноване на власних знаннях, досвіді студентів, інтерактивне навчання спрямоване на набуття ними нового досвіду, усвідомлення здобувачами освіти нових теоретичних знань через їх практичне застосування.

Засоби навчання, що пропонуються до використання: підручники, навчально-методичні посібники, електронні посібники, дидактичний матеріал (таблиці, схеми, картки тощо), засоби інформаційно-комунікаційних технологій.

Виконання означеної роботи дасть змогу поєднати теорію 3 практикою в умовах освітнього процесу закладу вищої педагогічної освіти, набути навичок у вирішенні студентами практичних завдань, тобто сприяти формуванню економічної компетентності майбутніх учителів технологій.

3 метою узагальнення та систематизації економічних знань студентів пропонуємо введення курсу за вибором «Основи формування економічної компетентності майбутніх учителів технологій», що націлює майбутніх фахівців на розвиток умінь щодо формування 
економічної компетентності учнів і забезпечує формування в них власної економічної компетентності.

Запропонований курс за вибором побудований у такий спосіб, щоб майбутні вчителі технологій, використовуючи методологічну і практичну складові, мали змогу не лише отримати знання, а й самостійно могли здійснювати пошук економічної, освітньої інформації 3 фаху, будувати логічні схеми, застосовувати набуту компетентність в освітньому процесі закладу вищої педагогічної освіти.

Предметом вивчення означеної вибіркової дисципліни $є$ процес формування економічної компетентності майбутніми вчителями технологій у процесі фахової підготовки.

У результаті вивчення курсу за вибором майбутні вчителі технологій повинні знати: Конституцію України, Закони України («Про освіту», «Про вищу освіту», «Про загальну середню освіту» та інші) та державні документи, що визначають основи політики української держави в галузі освіти (Концептуальні засади реформування середньої школи «Нова українська школа», Концептуальні засади розвитку педагогічної освіти в Україні та ii інтеграції в європейський освітній простір, Концепція профільного навчання у старшій школі, Національна стратегія розвитку освіти в Україні на період до 2021 року, Національна рамка кваліфікацій тощо); Державний стандарт базової i повної загальної середньої освіти; Кваліфікаційні характеристики професій (посад) педагогічних та науково-педагогічних працівників навчальних закладів; Концепцію розвитку економічної освіти в Україні; навчальні програми для закладів загальної середньої освіти з навчального предмета «Економіка» (рівень стандарту, профільний рівень); міжпредметні зв'язки навчального предмета «Економіка» та навчальних предметів освітньої галузі «Технології»; механізми функціонування економічної системи, ринкової економіки; специфіку економічних знань; смислову інтерпретацію понять: «компетентність», «професійна компетентність», «економічна компетентність», «економічна освіта»; методи і форми саморозвитку вчителя технологій; особливості сприйняття особистості вчителя технологій, що формує економічні знання, учнями та батьками.

Майбутні бакалаври у результаті опанування навчального матеріалу курсу за вибором повинні вміти: організовувати власну економічно орієнтовану педагогічну практику; використовувати різноманітні джерела знань та застосовувати їх під час вирішення професійних завдань; застосовувати економічні знання на практиці; використовувати педагогічні технології розвитку у своій професійній діяльності, сприяти становленню економічного мислення та формуванню економічної компетентності учнів; визначати мету саморозвитку економічної компетентності; сприяти створенню сприятливого для формування економічної компетентності освітнього середовища: організовувати й брати участь у освітніх та позааудиторних заходах, наукових семінарах, тренінгах.

Основними формами підготовки майбутніх бакалаврів є лекції, практичні заняття, самостійна та індивідуальна робота. Для активізації процесу формування економічної компетентності майбутніх учителів технологій ми використовували такі типи лекцій: лекціябесіда, лекція-діалог, проблемна лекція. Застосування таких типів лекцій забезпечило комунікативний зв'язок «викладач - студент»; прикладне спрямування навчального матеріалу курсу за вибором; встановлення рівня їхньої обізнаності з тем, що розглядалися; сприяння формуванню системного мислення студентів.

Для поглиблення і закріплення теоретичних знань, отриманих студентами під час лекцій або в процесі самостійної роботи; аналізу проблемних запитань; розширення, закріплення і поглиблення знань, умінь і навичок та способів їх отримання і застосування; контролю знань; розвитку критичного мислення; уміння переконувати, обгрунтовувати свою точку зору використовували семінарські й практичні заняття.

Проведення семінарських занять передбачало обговорення проблемних питань за темами цих навчальних дисциплін, розв'язання практичних задач та вирішення проблемних ситуацій. Під час цієї роботи проводилися розрахунки з використанням даних бухгалтерської звітності підприємств, збірників задач, практикумів, навчальні тренінги.

Попередня підготовка студентів до семінарів передбачала самостійну пошукову роботу, 
опрацювання ними літературних джерел, що мало стати підгрунтям для аргументованого викладу власної думки під час обговорень та дискусій.

Для роботи з економічним текстом, інформацією та термінологією, з метою оволодіння поняттєвим апаратом студентам була запропонована до використання методика картографії. Майбутні вчителі технологій, працюючи в малих групах, знаходили основні взаємозв'язки економічних термінів та понять, відображали їх у вигляді карти-креслення, моделі з метою найбільш повного й точного розкриття їх змісту. Використовуючи метод конспектування, здобувачі освіти письмово занотовували навчальний матеріал 3 наукових джерел у вигляді конспектування з поясненнями.

Самостійна робота студентів у межах вивчення навчального матеріалу курсу за вибором була спрямована на: опрацювання питань, пов'язаних 3 отриманням та структуруванням нової інформації (складання схем конспектів, підготовка до семінарських занять, написання есе, підготовка мультимедійних презентацій тощо); ознайомлення 3 нормативно-правовими актами (Законами України «Про освіту» та «Про вищу освіту», Державним стандартом вищої освіти, Держаним стандартом загальної середньої освіти, навчальними програмами 3 предмета «Економіка», навчальних предметів освітньої галузі «Технології» тощо); організацію виховних заходів з учнями основної школи в позаурочний час.

Запропонований курс за вибором спрямований на забезпечення: системності набутих економічних знань, умінь, навичок; формування економічного мислення; досвіду практичної діяльності майбутніх учителів технологій. Важливим аспектом при вивченні курсу за вибором «Основи формування економічної компетентності майбутніх учителів технологій» $\epsilon$ усвідомлення студентами специфіки: економічних знань, проведення уроків з наданням економічних знань учням, використання інноваційних та інформаційно-комунікаційних технологій у власній педагогічній діяльності.

3 метою забезпечення профільної освіти учнів за економічним напрямом запропоновано впровадженням економічного блоку у варіативну частину навчального плану магістрів дисциплін за вибором студентів «Мікроекономіка», «Макроекономіка», «Економіка підприємства», «Методика навчання економічних дисциплін».

Метою вивчення навчальної дисципліни «Методика навчання економічних дисциплін» $\epsilon$ підготовка майбутнього вчителя технологій до управління процесом економічної освіти учнів закладів загальної середньої освіти, формування економічної компетентності майбутніх учителів технологій, досягнення сучасного рівня викладання економічних дисциплін у закладах освіти.

У результаті засвоєння запропонованої навчальної дисципліни студенти повинні знати: теоретичні основи методики викладання економічних дисциплін; завдання, проблеми, тенденції розвитку економічної освіти; закони, принципи освітнього процесу, технології навчання, економічного виховання; місце та значення методики навчання економічних дисциплін у системі економічних дисциплін; вплив навчальної дисципліни «Методика навчання економічних дисциплін» на набуття цілісних, системних знань та формування економічної компетентності в процесі фахової підготовки майбутніх учителів технологій; структуру економічної підготовки у закладі вищої педагогічної освіти та міждисциплінарні зв'язки навчальної дисципліни «Методика навчання економічних дисциплін»; методику викладання економічних дисциплін у закладах вищої освіти. Майбутні вчителі технологій у результаті засвоєння навчальної дисципліни повинні вміти: ураховувати під час навчання міжпредметні зв'язки; реалізовувати зв'язок теорії з практикою; розробляти та застосовувати власну методичну систему; обирати технології та методи викладання економічних дисциплін; розробляти та проводити різні за формою заняття 3 економічних дисциплін; сприяти самореалізації здобувачів освіти під час навчання.

Основними формами підготовки майбутніх магістрів визначено лекції, практичні та лабораторні роботи, самостійну та індивідуальну роботу.

Під час викладання навчальної дисципліни «Методика навчання економічних 
дисциплін» посилений комунікаційний зв'язок «викладач - студент» шляхом упровадження таких організаційних форм занять: нетрадиційні лекції (лекція - зворотний зв'язок, лекція вдвох, лекція-консультація, лекція-аналіз, проблемна лекція, лекція-прес-конференція), семінарські заняття (конференція, рольова гра шляхом моделювання ситуації, колоквіум, розгорнута бесіда, заслуховування та обговорення, коментоване читання, конференція із запрошеними, моделювання практичних ситуацій), практичні роботи (побудова схеми організації навчального процесу із застосуванням інтерактивних методів навчання (практична робота з теми «Методи активізації навчально-пізнавальної діяльності студентів»), рольова гра, пов'язана 3 моделюванням ситуації 3 використанням інтерактивної методики «5 3 25» (практична робота за темою «Основні парадигми освіти та сучасні підходи в економічній освіті»), використання методу «Метаплан» за запропонованою викладачем тематикою навчальної дисципліни «Основи підприємницької діяльності» (практична робота «Методика організації самостійної роботи студентів»), навчальний тренінг із використанням рольових ігор, проблемний метод активізації освітньої діяльності (практична робота з теми «Контроль результатів навчання»), методи контекстного навчання, метод «Мозаїка» (з теми «Економічне виховання»), лабораторні роботи з розв'язанням економічних загадок, тестові завдання, самостійна та індивідуальна робота студентів.

У процесі навчання студентів 3 дисципліни «Методика навчання економічних дисциплін» пропонуємо застосовувати методи навчання, передбачені моделлю, а саме: проблемний, дискусія, ділова гра, круглий стіл, проектів, моделювання, інтерактивні («Сase Study», «5 3 25», «Мозаїка», «Метаплан», проблемний, контекстного навчання, економічні загадки).

Під час викладу майбутнім учителям технологій навчального матеріалу із запропонованих у нашому дослідженні економічних дисциплін ми враховували такі особливості вивчення економічних категорій:

1. Застосування прийому «нарощування» поняття, поглиблення його змістового компонента, коли думка рухається від простого до складного (за таксономією Б. Блума).

Так, під час вивчення питання «Організація переходу до випуску нових видів продукції» теми «Значення технічної та технологічної підготовки виробництва, іï завдання» навчальної дисципліни «Економіка і організація виробництва» виклад вибудовували в такій послідовності: технологічна підготовка виробництва, органи технологічної підготовки виробництва на підприємстві, технологічна уніфікація й стандартизація, економічна ефективність технологічних процесів, організаційна підготовка виробництва, перехід виробництв до випуску нових видів продукції.

2. «Відштовхування» від відомих понять та раніше вивченого навчального матеріалу.

Розгляд питання «Ціноутворення» теми «Витрати виробництва, собівартість та рентабельність продукції» навчальної дисципліни «Економіка і організація виробництва» було розпочато з повторення раніше вивченого навчального матеріалу: собівартість, прибуток, ціна виробника, податок на додану вартість, відпускна ціна виробника, посередницька надбавка, відпускна ціна посередника, торговельна надбавка, ціна реалізації товару споживачеві (роздрібна ціна).

3. Під час розгляду проблеми викладач наводив різні тлумачення термінів, категорій науковцями. Наприклад, розкриття змісту теми «Змістовий аспект поняття «економічної компетентність учителя технологій» та його структура» курсу за вибором «Основи формування економічної компетентності майбутніх учителів технологій» супроводжувалося категоріальним аналізом понять «компетентність», «професійна компетентність», «економічна компетентність» у науково-педагогічній літературі з урахуванням напрацювань та висновків нашого дослідження.

4. Застосування прийому зіставлення.

На семінарському занятті з теми «Програми для закладів загальної середньої освіти 3 навчального предмета «Економіка»« змістового модуля «Методика навчання економіки» навчальної дисципліни «Методика навчання технологій» викладач вів діалог зі студентською 
аудиторією, обмірковував та відповідав на запитання, застосовуючи прийом зіставлення. Таким чином ми домагалися активізації навчальної діяльності майбутніх бакалаврів, мотивували їх до засвоєння нового обсягу економічних знань 3 навчального предмета «Економіка», усвідомлення схожості та відмінності навчальних програм 3 цього предмета за всіма структурними компонентами, змістом навчального матеріалу та вимогами до навчальних досягнень учнів.

На запитання від аудиторії «Які міжпредметні зв'язки, визначені програмами, має навчальний предмет «Економіка»?» викладач, обгрунтовуючи взаємозв'язок зі змістом, на прикладах за темами цих навчальних предметів надавав відповідь: ««Всесвітня та вітчизняна історія», «Географія», «Математика», «Екологія», «Технології».

Розглянемо активізацію освітньої діяльності майбутніх учителів під час семінарського заняття 3 теми «Застосування інноваційних технологій навчання в процесі формування економічної компетентності майбутніх учителів технологій» курсу за вибором «Основи формування економічної компетентності майбутніх учителів технологій». Питання, винесені викладачем на опрацювання: сутність та значення технології проблемного навчання; особливості застосування технології інтерактивного навчання майбутніми вчителями технологій під час практики; проектна діяльність у системі економічного виховання майбутніх учителів технологій.

Засоби навчання, що пропонуються до використання у процесі фахової підготовки: підручники, електронні підручники, авторський навчально-методичний посібник навчальної дисципліни «Методика навчання економічних дисциплін» для студентів спеціальності 014.10 Середня освіта (Трудове навчання та технологіï) [3], дидактичний матеріал (таблиці, схеми, картки тощо), засоби інформаційно-комунікаційних технологій.

Ефективність третьої педагогічної умови - застосування інформаційно-комунікаційних технологій в освітньому процесі з метою формування економічної компетентності майбутніх учителів технологій - досягається під час підготовки студентів до навчальних занять, їхньої самостійної та індивідуальної роботи в процесі здобуття економічних знань. Майбутні вчителі технологій проводять самостійний інформаційний пошук, роботу з бібліотечними ресурсами за допомогою веб-браузерів Google Chrome, Internet Explorer, Mozilla Firefox, Opera. Отримана інформація оформлюється студентами згідно 3 вимогами кафедри, методичними рекомендаціями 3 використанням можливостей текстового редактора Microsoft Office Word, табличного процесора Microsoft Office Excel, програми Microsoft Office PowerPoint для створення мультимедійних презентацій. Авторський навчально-методичний посібник 3 навчальної дисципліни «Методика навчання економічних дисциплін» містить прикладні економічні задачі, тестові завдання тощо для вирішення студентами [3].

Невід’ємною складовою освітнього процесу є контроль результатів спільної діяльної викладача і студента, який виконує інформаційну, діагностичну, мотиваційну i виховну функції. Для контролю вивчення здобувачами освіти дисциплін економічного спрямування широко застосовують тестування, оскільки ця форма контролю поєднує методи та результати навчання, отримані від застосування цих методів. Перевагами тестування порівняно з іншими видами контролю є можливість одночасного охоплення опитуванням усіх студентів групи; швидке отримання результатів опитування студентів; можливість використання як засобу діагностики рівня знань для проведення спостереження за якістю освітнього процесу; використання як пробне опитування. 3 огляду на зазначені переваги тестування $\epsilon$ інструментом викладача для мотивації майбутніх учителів технологій до навчання на шляху підвищення в них рівня економічних знань, формування економічного мислення.

Застосування інформаційно-комунікаційних технологій у контролі та оцінюванні результатів навчання забезпечує об'єктивність отриманих кількісних та якісних оцінок рівня навчальних досягнень студентів. Для створення тестових завдань і визначення рівня засвоєння знань 3 навчальної дисципліни майбутніми вчителями технологій пропонуємо застосувати актуальний сервіс мережі Інтернет Google Диск.

Інформаційно-комунікаційні технології забезпечують роботу 3 економічною 
інформацією та економічними показниками, їх оброблення, систематизацію та узагальнення, аналіз та отримання висновків, створюючи необхідні передумови для ухвалення обгрунтованого рішення, спрямованого на ефективність діяльності виробництв і фахівців.

Реалізація четвертої педагогічної умови - запровадження завдань економічного змісту на технологічну і педагогічну практики - має прикладний характер на шляху досягнення поставленої мети - сформованості економічної компетентності майбутніх учителів технологій у процесі фахової підготовки. Підприємства промислового комплексу є потужним потенціалом розвитку економіки держави, вони формують вагому дохідну частину бюджету. Отже, економічна підготовка майбутніх фахівців здатна забезпечити їх компетентність у визначенні шляхів ефективної фінансово-господарської діяльності суб'єктів господарювання; сутності економічного механізму планування, функціонування виробничих підприємств; оволодінні методами економічного розрахунку, аналізу й обгрунтування ухвалених рішень. Означену специфіку враховують розроблені методичні рекомендації до виконання майбутніми бакалаврами запропонованого спектру завдань економічного змісту на технологічну практику.

3 метою виконання завдань економічного змісту на технологічну практику, застосовуючи алгоритм, розроблений у дослідженні, бачимо, що майбутні вчителі технологій набувають та поглиблюють економічні знання, уміння за всіма трьома організаційними блоками алгоритму: систематизація економічних знань, набуття навичок роботи 3 документами, аналітичне опрацювання документів діяльності суб'єкта господарювання. Аналітичне опрацювання документів супроводжується розв'язанням студентами прикладних економічних задач щодо діяльності суб'єктів господарювання 3 використанням теоретичних економічних знань, що знаходить відображення у звіті про проходження технологічної практики.

Поглиблення та закріплення економічних знань має продовження під час вивчення студентами навчальної дисципліни «Методика навчання економічних дисциплін» та виконання спектру практичних робіт, запропонованих у авторському навчально-методичному посібнику дисципліни [3; 4].

Стосовно виконання завдань економічного змісту на педагогічну практику зазначимо, що на четвертому курсі під час проходження навчально-залікової педагогічної практики в 59 класах закладів загальної середньої освіти, виконуючи функції класного керівника та вчителя, майбутні вчителі технологій спрямовують свою діяльність на:

- оволодіння навичками ведення уроків різних типів, методами навчання для забезпечення активізації пізнавальної діяльності учнів та формування в них економічної компетентності з урахуванням міжпредметних зв' язків, а саме (в частині нашого дослідження):

- розроблення планів-конспектів і проведення пробних уроків із трудового навчання, креслення, економіки; економіки;

- розроблення планів-конспектів залікових уроків із трудового навчання, креслення,

- формування навичок застосування методів активного та інтерактивного навчання при розкритті змісту економічних категорій (у частині нашого дослідження):

- проведення 6/4 залікових уроків із трудового навчання, серед яких 1 - із креслення, 1 - із економіки;

- проведення занять предметних гуртків.

Отже, проходження педагогічної практики студентами сприяє підвищенню рівня їхньої фахової підготовки, мотивації, забезпечує формування економічного мислення та економічної компетентності.

Висновки. Схарактеризовано методику формування економічної компетентності майбутніх учителів технологій у процесі фахової підготовки, в основу якої покладено організацію цілісного процесу, що обумовлює функціонування компонентів змістової підготовки. Вона охоплює взаємопов'язані форми: загальні (індивідуальні, парні, групові, колективні), конкретні (спеціальні); методи, як-от: проблемний, дискусія, ділова гра, круглий стіл, проектів, моделювання, інтерактивні «Case Study», «5 з 25», «Мозаїка», «Метаплан», метод контекстного навчання, економічні загадки, тести, в тому числі із застосуванням 
актуального сервісу мережі Інтернет Google та його функції Google Форми. Реалізація методики в освітньому процесі забезпечується навчально-методичним супроводом навчальних дисциплін циклів гуманітарної та соціально-економічної, професійної та практичної підготовки, варіативної частини навчального плану дисциплін за вибором студентів, а також педагогічної та технологічної практик.

Запропоновані нами форми і методи ефективної їх реалізації підлягають перевірці за допомогою контрольної діагностики за встановленими критеріями й обраними методиками педагогічного експерименту, також передбачено порівняння отриманих результатів.

\title{
Список використаної літератури
}

1. Великий тлумачний словник сучасної української мови (з дод. і допов.)/ Уклад. і голов. ред. В. Т. Бусел. Київ; Ірпінь, 2005. 1728 с.

2. Ковтун О. В. Навчально-методичний супровід процесу формування професійного мовлення у майбутніх фахівців авіаційної галузі. Сучасні соиіально-гуманітарні дискурси: матеріали II всеукр. наук. конф. 3 міжнар. участю (м. Дніпропетровськ, 20 жовтня 2012). Дніпропетровськ, 2012. Ч. 1. С. 54-58.

3. Кондратенко Т. В. Методика навчання економічних дисциплін: навчально-методичний посібник для студентів спеціальності 014.10 Середня освіта (Трудове навчання та технології) галузі знань 01 Освіта/Педагогіка. Суми, 2018. $138 \mathrm{c}$.

4. Курок В. П., Кондратенко Т. В. Компетентностый поход к подготовке учителя общеобразовательного учебного заведения в обеспечении экономического образования старшеклассников. Вестник Казахского гуманитарно-юридического инновационного университета. 2016. № 4 (32). С. 117-121.

5. Програма для загальноосвітніх навчальних закладів. Трудове навчання 5-9 класи. URL: https://osvita.ua/school/program/program-5-9/56126/(дата звернення: 30.03.2018).

6. Филатова О. Н., Прохорова М. П. Разработка методического сопровождения инновационной подготовки педагогов в ВУЗе. Современные проблемы науки и образования. 2015. № 4. URL: http://scienceeducation.ru/ru/article/view?id=20908 (дата звернення: 18.05.2016).

\section{EDUCATIONAL AND METHODICAL SUPPORT OF FUTURE TECHNOLOGIES TEACHERS' ECONOMIC COMPETENCE FORMING}

\author{
Kurok Vira \\ Pedagogical sciences doctor, professor, head of Technological and Professional education chair, \\ Oleksandr Dovzhenko Hlukhiv national pedagogical university
}

\author{
Kondratenko Tetyana \\ Pedagogical sciences candidate, \\ Oleksandr Dovzhenko Hlukhiv national pedagogical university
}

Introduction. In order to ensure professional training of a competitive teacher in modern conditions the higher educational institution should work out and implement a personally oriented model. Interdisciplinary connections of the educational branch "Technologies» and economic disciplines in educational process of secondary schools have actualized the problem of future Technologies teachers' economic competence forming. Under these circumstances creating educational and methodological support for this process becomes logical.

Purpose. The article is aimed at substantiating educational and methodological support of future Technologies teachers' economic competence forming in the process of their professional training.

Methods. Theoretical, empirical.

Results. The educational and methodological support of future Technologies teachers' economic competence forming is defined as a complex of educational and methodological documents and teaching aids aimed at implementing pedagogical conditions (forming future specialists' positive motivation to acquiring economic knowledge; improving the content of future Technologies teachers' economic training at institutions of higher pedagogical education; applying information and communication technologies in the educational process with the purpose of future Technologies teachers economic competence forming; introducing economic content tasks for technological and pedagogical practice and resultful functioning of the model.

Originality. The educational and methodical support of future Technologies teachers' 
economic competence forming in the process of their professional training as a complex of educational and methodical documents and training tools is worked out.

Conclusion. Methodics of future Technologies teachers' economic competence forming in the process of their professional training is characterized, which is based on organizing holistic process that determines functioning of content training components. It covers such interconnected forms: general (individual, paired, group, collective), concrete (special); methods, such as: problem, discussion, business game, round table, projects, simulation, interactive «Case Study», 5 from 25», "Mosaic», "Metaplan», context learning method, economic riddles, tests using Google's online service and Google Forms. Realizing of methodology in the educational process is ensured by the educational and methodical support of academic disciplines in particular the humanities and socioeconomic, professional and practical training courses, the variative part of the curriculum as well as the disciplines of the students' choice and pedagogical and technological practices.

Mentioned above forms and methods of implementing pedagogical conditions are to be verified by means of control diagnostic tools according to the defined criteria and chosen methodics and the obtained results should be compared.

Keywords. future Technologies teachers, economic competence, pedagogical conditions, educational and methodological support

\title{
References
}

1. Busel, V. T. (2005). Velykyi tlumachnyi slovnyk suchasnoi ukrainskoi movy [The great is explanatory dictionary of the modern Ukrainian a language], Irpin, Ukraine. 1728 [in Ukrainian].

2. Kovtun, O. V. (2012). The educational-accompaniment support for the process of the forming professional broadcasting for future the specialists in the aviation of industry. Suchasni sotsialno-humanitarni dyskursy [The modern the social and humanitarian discourses], (Dnipropetrovsk, 20 October 2012), Dnipropetrovsk, part 1, p. 54-58 [in Ukrainian].

3. Kondratenko, T. V. (2018) The methodology of the teaching of economic this disciplines: of the educationalmethodical manual for students of the specialty 014.10 Secondary education (the of labor training and technology) of the field of knowledge 01 Education / Pedagogy [Metodyka navchannia ekonomichnykh dystsyplin: navchalno-metodychnyi posibnyk dlia studentiv spetsialnosti 014.10 Serednia osvita (Trudove navchannia ta tekhnolohii) haluzi znan 01 Osvita/Pedahohika], Sumy, Ukraine. 138 [in Ukrainian].

4. Kurok, V. P., Kondratenko, T. V. (2016) The competence the approach to the preparation in teachers of general educational of the institutions in the provision of the economic education of the high school the students. Bulletin of Kazakh humanitarian juridical innovative university. № 4 (32). 117-121 [in Russian].

5. Prohrama dlia zahalnoosvitnikh navchalnykh zakladiv. Trudove navchannia 5-9 klasy, available at: https://osvita.ua/school/program/program-5-9/56126/(access date March 30, 2018) [in Ukrainian].

6. Fylatova, O. N., Prokhorova, M. P. (2015). Development of the methodical support of is innovative training of teachers in the higher educational institutions, available at: http://science-education.ru/ru/article/view?id=20908 (access date May 18, 2016) [in Russian].

\section{УЧЕБНО-МЕТОДИЧЕСКОЕ СОПРОВОЖДЕНИЕ ФОРМИРОВАНИЯ ЭКОНОМИЧЕСКОЙ КОМПЕТЕНТНОСТИ БУДУЩИХ УЧИТЕЛЕЙ ТЕХНОЛОГИЙ}

\author{
Курок Вера Афанасьевна \\ доктор педагогических наук, профессор, заведующая кафедрой технологического и \\ профессионального образования \\ Глуховский нацииональный педагогический университет имени Александра Довженко
}

\section{Кондратенко Татьяна Владимировна}

кандидат педагогических наук

Глуховский нацииональный педагогический университет имени Александра Довженко

\begin{abstract}
Определена сущзность учебно-методического сопровождения формирования экономической компетентности будущчих учителей технологий как комплекс учебно-методической документации и средств обучения, направленных на реализачию педагогических условий и эффективное функиионирование разработанной модели. Очерчены направления формирования экономической компетентности соискателей образования в процессе профессиональной подготовки. Охарактеризовань отдельные формыл и методы формирования указанного качества будущих спещиалистов с учетом педагогических условий и путей их эффективной реализации.

Ключевые слова: будущчие учителя технологий, экономическая компетентность, педагогическое условие, учебно-методическое сопровождение.
\end{abstract}

Отримано редакцією 10.06 .2019 p. 